\title{
Methylenetetrahydrofolate reductase gene polymorphism in Indian stroke patients
}

\author{
J. Kalita, R. Srivastava, V. Bansal, S. Agarwal ${ }^{\star}$, U. K. Misra \\ Departments of Neurology and *Genetics, Sanjay Gandhi PGIMS, Lucknow - 226 014, India
}

Background and Aims: In view of the prevailing controversy about the role of Methylenetetrahydrofolate reductase (MTHFR) C677T mutation in stroke and paucity of studies from India, this study has been undertaken to evaluate MTHFR C677T gene polymorphism in consecutive ischemic stroke patients and correlate these with folic acid, homocysteine (Hcy) and conventional risk factors. Settings and Design: Ischemic stroke patients prospectively evaluated in a tertiary care teaching hospital. Materials and Methods: Computerized tomography proven ischemic stroke patients were prospectively evaluated including clinical, family history of stroke, dietary habits and addictions. Their fasting and postprandial blood sugar, lipid profile, vitamin B12, folic acid and MTHFR gene analysis were done. Statistical Analysis: MTHFR gene polymorphism was correlated with serum folic acid, Vitamin B12 and Hcy levels; family history of stroke in first-degree relatives; and dietary habits; employing Chi-square test. Results: There were 58 patients with ischemic stroke, whose mean age was 50 (479) years; among them, 10 were females. MTHFR gene polymorphism was present in $19(32.8 \%)$ patients, 3 were homozygous and 16 were heterozygous. Both serum folate and B12 levels were low in 29 (50\%) patients and Hcy in 48 (83\%). Hypertension was present in $28(48 \%)$ patients, diabetes in $12(21 \%)$, hyperlipidemia in $52(90 \%)$, smoking in $17(29 \%)$, obesity in $1(1.7 \%)$ and family history of stroke in first-degree relatives in $13(22.4 \%)$. There was no significant relationship of MTHFR gene polymorphism with folic acid, B12, Hcy levels, dietary habits and number of risk factors. Vitamin B12 level was low in vegetarians $(P<0.003)$. In 3 patients with MTHFR TT alleles, Hcy was elevated in all 3 , low folic acid in 2 and family history of stroke in 1 patient. Conclusion: MTHFR gene polymorphism was found in onethird of patients with ischemic stroke and was insignificantly associated with higher frequency of elevated Hcy.

Key words: Diet, folic acid, homocysteine, Infarction, methylenetetrahydrofolate reductase, stroke, vegetarianism, vitamin B12

\section{Introduction}

More than 110 heritable disorders, 175 genetic loci and 2,050 unique mutations predisposing to stroke are known. Although ischemic stroke can result from merely one genetic defect, the interaction of unfavorable genetic factors such as Leiden $\mathrm{V}$, Methylenetetrahydrofolate reductase (MTHFR) 677T, apoliprotein E (ApoE) 4 and angiotensin converting enzyme (ACE) D/D genotypes with other risk factors such as hypertension, diabetes, smoking and alcohol consumption can influence the occurrence of stroke. ${ }^{[1-3]}$ Elevation of homocysteine (Hcy) is a recently established risk factor for cardiovascular disease. ${ }^{[4-6]}$ The role of homocysteine in stroke however remains controversial, though most case-control studies suggest a positive association between homocysteine and stroke. ${ }^{[5,7,8]}$ But the association has not been established in nested case control studies ${ }^{[9,10]}$ MTHFR is an enzyme in modulation of plasma homocysteine by converting it into methionine. Polymorphism of MTHFR C677T leads to a reduction in enzyme activity and subsequent elevation of plasma homocysteine. The C677T mutation has been reported to be associated with ischemic stroke in some studies ${ }^{[11,12]}$ but not in others. ${ }^{[13]}$ Variation in ethnicity and methodological differences could account for this discrepancy.

The population frequency of $\mathrm{C} 677 \mathrm{~T}$ homozygosity ranges from $1 \%$ or less among blacks to $20 \%$ amongst Italians and US Hispanics. ${ }^{[7]}$ In the pooled analysis of several thousand Japanese, the frequency of C677T homozygosity was $11 \%$ and limited data are available for other Asian population. ${ }^{[14]}$ We report preliminary results of a study evaluating MTHFR C677T mutations in Indian ischemic stroke patients and correlate these with folic acid and homocysteine levels in the context of other risk factors.

\section{Materials and Methods}

In this study, computerized tomography proven ischemic stroke patients attending to the department of Neurology during January to October 2005 were prospectively evaluated. The project was duly approved by the local ethics committee. The patients 
with endocrine disorders other than diabetes mellitus (DM); cardiogenic stroke; liver failure; pregnancy; malignant disease; vasculitis; and those with exposure to nitric oxide, methotrexate or other folic acid inhibitors were excluded. Those who received B12 or folic acid supplementation in the past 1 year were also excluded.

The patients were subjected to detailed medical history and clinical examination. The medical history also included family history of stroke in the first-degree relatives. Dietary history was taken by food frequency questionnaire employing recall of food items in 1 week and daily intake of vitamin B12 was calculated.

The risk factors of stroke such as hypertension $(\geq 140 / 90$ $\mathrm{mmHg}$ ), diabetes (blood sugar $\geq 106$ and $2 \mathrm{~h}$ postprandial $>$ $200 \mathrm{mg} / \mathrm{dl}$ ) and hyperlipidemia [high density lipoprotein (HDL) $<40 \mathrm{mg} / \mathrm{dl}$, low density lipoprotein (LDL) >160 mg/dl, triglyceride $>150 \mathrm{mg} / \mathrm{dl}$, very low density lipoprotein (VLDL) $>30 \mathrm{mg} / \mathrm{dl}$ and total cholesterol $>200 \mathrm{mg} / \mathrm{dl}]^{[15]}$ were recorded. For diagnosis of hyperlipidemia, values of fasting blood lipid after 1 month of stroke were considered. History of smoking (pack/ year), tobacco and alcohol intake were also noted. Body mass index was calculated as weight in $\mathrm{kg} /$ height in $\mathrm{m}^{2}$. The neurological examination included the severity of stroke as defined by Canadian neurological scale. ${ }^{[16]}$ The patients were subjected to 12-lead electrocardiogram (ECG) and echocardiography, blood counts, red blood cell (RBC) morphology, hemoglobin, mean corpuscular volume (MCV), serum protein, serum creatinine and blood urea nitrogen (BUN) estimation.

After 3 months of stroke, fasting blood was drawn by venipuncture and stored at $-70^{\circ} \mathrm{C}$. It was centrifuged and serum was analyzed for B12, ${ }^{[17]}$ folic acid ${ }^{[17]}$ and homocysteine, ${ }^{[18]}$ using ADVIA Centaur assay (Bayer Corporation). It is a competitive immunoassay using direct chemiluminescent technology. The lower limit of folic acid in normal was $5.38 \mathrm{ng} / \mathrm{ml}$ and B12 was $211 \mathrm{pg} /$ $\mathrm{ml}$. The upper limit of Hcy in normal was $13.9 \mathrm{~mol} / \mathrm{l}$ as per laboratory standard.

\section{MTHFR gene analysis}

Deoxyribonucleic acid (DNA) was extracted from peripheral leukocyte with the use of commercially available kit (NUCLEON, Stotlab Ltd., USA). MTHFR C-T677 substitution was identified with the use of restriction enzyme digestion of the polymerase chain reaction (PCR) amplified products. ${ }^{[19]}$ 5'-TGAA GGAGAA GGTGTCTGCG GGA-3' (exonic) and 5'AGG ACGG TGC GGTG AGAGTG-3' (intronic) primers were used. This generates a 198-bp fragment. The C-T substitution creates HinfI recognition sequence and digestion of the nutrient product results in 175and 23- BP fragments. The fragment size was determined by gel electrophoresis.

\section{Statistical analysis}

MTHFR gene polymorphism was correlated with various demographic, clinical and laboratory parameters, i.e., folic acid, B12 and homocysteine levels employing Chi-square and Fisher exact tests using SPSS 10 version software. Two-sided ' $P$ ' value was considered significant if it was $<0.05$.

\section{Results}

There were 58 patients with ischemic stroke, whose mean age was 50 (range 4-79) years; among them, 10 were females. The stroke was in middle cerebral arterial (MCA) territory in 45, posterior cerebral arterial (PCA) territory in 10 and involved multiple territories in 3 patients. The infarctions were cortical in 23 , subcortical in 26, both cortical and subcortical in 2 and were located in brainstem in 7 patients. Carotid artery stenosis in the range of $50-80 \%$ was present in 4 and more than $80 \%$ in 9 patients.

MTHFR gene polymorphism (C677T) was noted in 19 $(32.8 \%)$ patients, 3 patients were homozygous (T'T) and 16 were heterozygous (TC) [Figure 1]. Both serum folate and B12 levels were low in $29(50 \%)$ patients and serum homocysteine was elevated in $48(83 \%)$ patients. The distribution of conventional risk factors in stroke patients included hypertension in 28 (48\%), diabetes mellitus in $12(21 \%)$, hyperlipidemia in $52(90 \%)$, smoking in 17 (29\%) and obesity in 1 (1.7\%) patient. Family history of stroke in first-degree relatives was present in $13(22.4 \%)$ patients. Fourteen patients consumed alcohol. In the patients with hyperlipidemia, total cholesterol was raised in 7 , triglyceride in 29, VLDL in 25 and low HDL in 38 patients. However, LDL above $160 \mathrm{mg} / \mathrm{dl}$ was present in $8(13.8 \%$ ) patients only.

The relationship of MTHFR gene polymorphism with folic acid, homocysteine and family history of stroke is shown in Table 1. Comparison of serum folic acid $\left(\mathrm{x}^{2}=0.09\right.$, df $\left.=1, P=0.78\right)$, B12 ( $\mathrm{x}^{2}=0.16$, df $\left.=1, P=0.69\right)$, homocysteine $\left(\mathrm{x}^{2}=0.07\right.$, df $=1, P=0.79)$, dietary habits $\left(\mathrm{x}^{2}=0.31\right.$, $\left.\mathrm{df}=1, P=0.58\right)$ and the number of risk factors $\left(\mathrm{x}^{2}=0.003\right.$, $\left.\mathrm{df}=1, P=0.95\right)$ in patients with MTHFR polymorphism and without it revealed no significant difference [Figure 2]. However, serum B12 levels were significantly lower in vegetarians $\left(\mathrm{x}^{2}=9.21\right.$, $\left.\mathrm{df}=1, P=0.003\right)$, but vegetarianism was not correlated with folic acid $\left(\mathrm{x}^{2}=0.35, \mathrm{df}\right.$ $=1, P=0.77)$ and serum homocysteine $\left(\mathrm{x}^{2}=0.89\right.$, $\mathrm{df}=1, P=$ $0.43)$. The distribution of various conventional risk factors in relation to MTHFR polymorphism is summarized in Table 2.

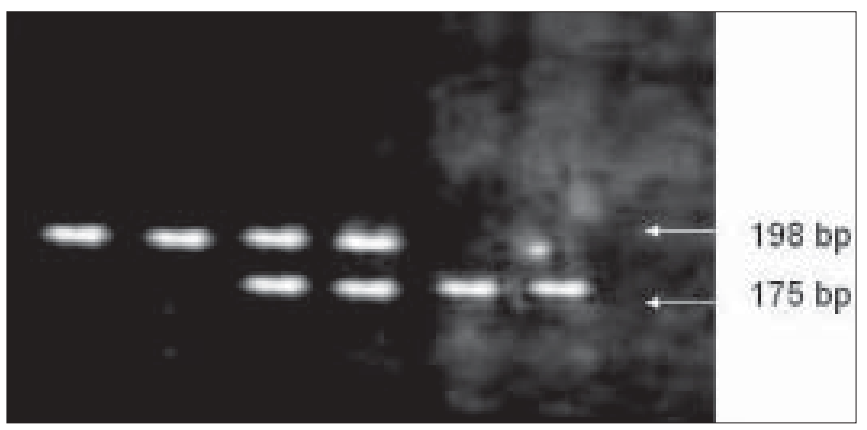

Figure 1: Methylenetetrahydrofolate reductase gene polymorphism in stroke patients: Lane 1 and 2 CC (Wild), Lane 3 and 4 CT (Heterozygous) and Lane 5 and 6 TT (Homozygous) 
Table 1: Clinical and biochemical characteristics of the stroke patients with methylenetetrahydrofolate reductase (MTHFR) polymorphism

\begin{tabular}{|c|c|c|c|c|c|c|c|}
\hline Age & Sex & Veg/non veg & $\begin{array}{c}\text { Location and type } \\
\text { of stroke }\end{array}$ & MTHFR & $\begin{array}{c}\text { FA } \\
(\mathrm{N} \geq 5.38 \mathrm{ng} / \mathrm{L})\end{array}$ & $\begin{array}{c}\text { Hcy } \\
(\mathrm{N} \leq 13.9 \mu \mathrm{mol} / \mathrm{l})\end{array}$ & FH stroke \\
\hline 52 & $M$ & V & MCASC & $\pi$ & 4.93 & 49.58 & - \\
\hline 55 & M & NV & MCA cortical & $\pi$ & 3.59 & 16.44 & + \\
\hline 59 & M & V & R. Cerebellar & $\pi$ & 6.30 & 45.30 & - \\
\hline 57 & $M$ & V & PCA occipital & CT & 5.73 & 22.7 & - \\
\hline 42 & $M$ & NV & MCASC & CT & 5.44 & 17.30 & - \\
\hline 51 & $M$ & NV & MCA B/L SC & CT & 4.76 & 20.17 & - \\
\hline 56 & $M$ & NV & MCA SC & CT & 4.24 & 41.36 & + \\
\hline 56 & $M$ & V & PCA brainstem & CT & 24.00 & 31.25 & - \\
\hline 40 & M & NV & PCA cortical & CT & 9.02 & 18.45 & - \\
\hline 44 & $M$ & NV & MCA cortical & CT & 7.51 & 15.40 & - \\
\hline 10 & $\mathrm{~F}$ & V & MCA cortical & CT & 4.37 & 13.69 & - \\
\hline 60 & $\mathrm{~F}$ & V & MCASC & CT & 4.87 & - & + \\
\hline 4 & $M$ & NV & MCA & CT & - & 8.8 & - \\
\hline 61 & $\mathrm{~F}$ & NV & MCA SC & CT & 3.38 & 35.94 & - \\
\hline 32 & $\mathrm{~F}$ & NV & MCA cortical & CT & 3.54 & 17.16 & - \\
\hline 79 & $\mathrm{~F}$ & V & MCA SC & CT & 12.8 & 27.73 & - \\
\hline 30 & $M$ & NV & MCA SC & CT & 3.32 & 18.74 & - \\
\hline 61 & $M$ & NV & MCA cortical & CT & 2.84 & - & + \\
\hline 70 & $M$ & $\mathrm{~V}$ & Multiple & CT & 7.07 & 17.26 & - \\
\hline
\end{tabular}

$\mathrm{MCA}=$ Middle cerebral artery, $\mathrm{PCA}=$ Posterior cerebral artery, $\mathrm{SC}=$ Subcortical, $\mathrm{M}=$ Male, $\mathrm{F}=$ Female, $\mathrm{V}=$ Vegetarian, $\mathrm{NV}=\mathrm{Non}$-vegetarian, $\mathrm{FH}=\mathrm{Family}$ history, $\mathrm{N}=$ Normal, $\mathrm{TT}=$ Homozygous, $\mathrm{CT}=$ Heterozygous

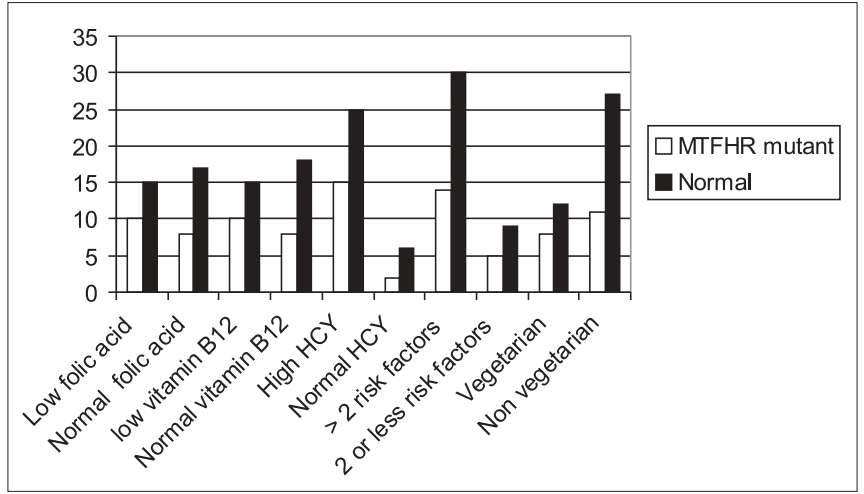

Figure 2: Relationship of various risk factors with methylenetetrahydrofolate reductase gene polymorphism

\section{Discussion}

In our study of 58 patients with ischemic stroke, $19(32.8 \%)$ had MTHFR C677T gene polymorphism, 3 were homozygous (TT), 16 heterozygous (TC) and remaining 39 were normal (CC). The frequency of MTHFR gene mutation is quite variable in different geographic and ethnic groups: 38\% in French Canadian, $5-15 \%$ in Canadian, ${ }^{[19,20]} 11 \%$ in Japanese and $12.3 \%$ in Chinese populations. ${ }^{[7,21]}$ In India, the reported frequency of MTHFR gene polymorphism in arterial stroke is $28-32 \%$ patients. ${ }^{[22,23]}$

In our study, 3 patients were homozygous and had high Hey in all, low folic acid in 2 and history of stroke in 1 . In the heterozygous group, serum Hcy was elevated in 12, reduced folic acid in 8 and family history of stroke in 3 patients. The comparison of different risk factors in TT, TC and CC alleles of MTHFR gene mutation in stroke patients did not reveal any statistically significant difference; however, lower levels of serum folate and higher level of homocysteine in the TT and TC alleles were noted. Significantly
Table 2: Various risk factors in respect of methylenetetrahydrofolate reductase (MTHFR) gene polymorphism

\begin{tabular}{lcccc}
\hline $\begin{array}{l}\text { MTHFR } \\
\text { polymorphism }\end{array}$ & $\begin{array}{c}\text { TT } \\
(\mathbf{n}=3)\end{array}$ & $\begin{array}{c}\text { TC } \\
(\mathbf{n}=16)\end{array}$ & $\begin{array}{c}\text { CC } \\
(\mathbf{n}=39)\end{array}$ & $\mathbf{X}^{2} / \mathbf{d f} / \mathbf{p}$ \\
Family history of stroke & 1 & 3 & 9 & $0.34 / 2 / 0.84$ \\
Diabetes mellitus & 0 & 4 & 8 & $0.96 / 2 / 0.62$ \\
Hyperlipidemia & 3 & 15 & 34 & $0.89 / 2 / 0.64$ \\
LVH & 1 & 3 & 9 & $0.34 / 2 / 0.84$ \\
BMl>25 & 1 & 7 & 10 & $1.75 / 2 / 0.42$ \\
Sedentary & 3 & 8 & 26 & $10.13 / 2 / 0.001$ \\
Tobacco & 1 & 8 & 18 & $3.06 / 2 / 0.22$ \\
Alcohol & 1 & 3 & 10 & $0.20 / 2 / 0.91$ \\
Hypertension & 3 & 7 & 18 & $3.42 / 2 / 0.18$ \\
\hline
\end{tabular}

$\mathrm{LVH}=$ Left ventricular hypertrophy, $\mathrm{BMI}=$ Body mass index, $\mathrm{TT}=$ Homozygous $\mathrm{TC}=$ Heterozygous, $\mathrm{CC}=$ Wild type

lower folate levels in MTHFR homozygotes were reported in patients with late onset vascular disease. ${ }^{[24,25]}$

Normal MTHFR helps in maintaining a pool of folate and methionine and possibly prevents elevation of homocysteine. In our study, homocysteine levels were highest in TT alleles compared to $\mathrm{TC}$ and $\mathrm{CC}$, although the difference was not significant. The requirement of 5-methyltetrahydrofolate as a methyl group donor for conversion of methionine to homocysteine might explain marginal rise of serum homocysteine in homozygous patients. Hyperhomocysteinemia is a risk factor for thrombotic disorder and MTHFR polymorphism has been reported to be a risk factor of myocardial infarction, cerebral stroke and silent brain infarction. ${ }^{[11,19,26,27]}$ The influence of MTHFR genotype on Hcy is greater in individuals with low serum folate and B12 levels. ${ }^{[28]}$

In our study, insignificantly higher frequency of hyperhomocysteinemia was noted in patients with MTHFR gene polymorphism. Hyperhomocysteinemia is multifactorial; dietary vitamins such as B12 and pyridoxine also have an important 
influence. In our study, vegetarians had low serum B12 compared to non-vegetarians. Folic acid levels in vegetarians and nonvegetarians were not significantly different. It is possible that in a typical Indian diet, inclusion of high pulses and vegetables may make up for the folate deficiency even in the MTHFR polymorphic patients. Moreover, the levels of serum B12 and pyridoxine may also be influenced by genetic predisposition, which have not been evaluated in the present study.

In our study, MTHFR gene polymorphism was found in onethird of patients with ischemic stroke and was associated with insignificantly higher frequency of hyperhomocysteinemia compared to those without polymorphism. Presence of MTFHR polymorphism may facilitate the effect of other risk factors of stroke. The lack of significance in our study may be due to small sample size; hence further study is needed in larger population.

\section{Acknowledgment}

This study was supported by the Indian Council of Medical Research, India (No.-SWG/ Neuro/16/2002-NCD-1).

\section{References}

1. Szolnoki Z. Evaluation of the interactions of common genetic mutations in stroke. Methods Mol Med 2005;104:241-50.

2. Szolnoki Z, Somogyvari F, Kondaes A, Szabo M, Fodor L. Evaluation of the interactions of common genetic mutations in stroke subtypes. J Neurol 2002;249:1391-7.

3. Szolnoki Z, Somogyvari F, Kondaes A, Szabo M, Fodor L, Bene J, et al. Evaluation of the modifying effects of unfavourable genotypes on classical clinical risk factors for ischemic stroke. J Neurol Neurosurg Psychiatr 2003;74:1615-20.

4. Graham IM, Daly LE, Refsum HM, Robinson K, Brattstrom LE, Ueland PM, et al. Plasma homocysteine as a risk factor for vascular disease. The European Concerted Action Project. JAMA 1997;277:1775-81.

5. Perry IJ, Refsum H, Morris RW, Ebrahim SB, Ueland PM, Shaper AG. Prospective study of serum total homocysteine concentration and risk of stroke in middle-aged British men. Lancet 1995;346:1395-8.

6. Madonna P, de Stefano V, Coppola A, Cirillo F, Cerbone AM, Orefice G, et al. Hyperhomocysteinemia and other inherited prothrombotic conditions in young adults with a history of ischemic stroke. Stroke 2002;33:51-6.

7. Botto LD, Yang Q. 5,10-Methylenetetrahydrofolate reductase gene variants and congenital anomalies: A Huge review. Am J Epidemiol 2000;151:862-77.

8. Giles WH, Croft JB, Greenlund K.J, Ford ES, Kittner SJ. Total homocyst(e)ine concentration and the likelihood of nonfatal stroke: Results from the Third National Health and Nutrition Examination Survey, 1988-1994. Stroke 1998;29:2473-7.

9. Verhoef P, Hennekens CH, Malinow MR, Kok FJ, Willett WC, Stampfer M.J. A prospective study of plasma homocyst(e)ine and risk of ischemic stroke. Stroke 1994;25:1924-30.

10. Alfthan G, Pekkanen J, Jauhiainen M, Pitkaniemi J, Karvonen M, Tuomilehto J, et al. Relation of serum homocysteine and lipoprotein (a) concentrations to atherosclerotic disease in a prospective Finnish population based study.
Atherosclerosis 1994;106:9-19

11. Morita H, Taguchi J, Kurihara H, Kitaoka M, Kaneda H, Kurihara Y, et al. Genetic polymorphism of 5,10-methylenetetrahydrofolate reductase (MTHFR) as a risk factor for coronary artery disease. Circulation 1997;95:2032-6.

12. Soriente L, Coppola A, Madonna P, Cerbone AM, Di Minno G, Orefice G, et al. Homozygous C677T mutation of the 5, 10 methylenetetrahydrofolate reductase gene and hyperhomocysteinemia in Italian patients with a history of early-onset ischemic stroke. Stroke 1998;29:869-71.

13. Brattstrom L, Wilcken DE, Ohrvik J, Brudin L. Common methylenetetrahydro folate reductase gene mutation leads to hyperhomocysteinemia but not to vascular disease: The result of a meta-analysis. Circulation 1998;98:2520-6

14. Schneider JA, Rees DC, Liu YT, Clegg JB. Worldwide distribution of a common methylenetetrahydrofolate reductase mutation. Am J Hum Genet. 1998;62:1258-60.

15. Expert Panel on Detection, Evaluation and Treatment of High Blood Cholesterol in Adults, Executive Summary of the Third Report of the National Cholesterol Education Program (NCEP) Expert Panel on Detection, Evaluation and Treatment of High Blood Cholesterol in Adults (Adult Treatment Panel III). JAMA 2001;285:2486-97.

16. Cote R, Hachinski VC, Shurrell BL, Norris BW, Wolfson C. The Canadian Neurological Scale: A preliminary study in acute stroke. Stroke 1986;17:731-7.

17. Schulpis K, Spiropoulos A, Gavili S, Karikas G, Grigori C, Vlachos G, et al. Maternal - neonatal folate and vitamin B12 serum concentrations in Greeks and in Albanian immigrants. J Hum Nutr Diet 2004;17:443-8

18. Demuth K, Ducros V, Michelsohn S, Paul .JL. Evaluation of Advia Centau automated chemiluminescence immunoassay for determining total homocysteine in plasma. Clin Chim Acta 2004;349:113-20.

19. Frosst P, Blom HJ, Milos R, Goyette P, Sheppard CA, Matthews RG, et al. A candidate genetic risk factor for vascular disease: A common mutation in methylenetetrahydrofolate reductase. Nat Genet 1995;10:111-3.

20. Arruda VR, Siqueira LH, Goncalves MS, von Zuben PM, Soares MC, Menezes R, et al. Prevalence of the mutation $\mathrm{C} 677 \rightarrow \mathrm{T}$ in the methylene tetrahydrofolate reductase gene among distinct ethnic groups in Brazil. Am J Med Genet 1998;78:332-5.

21. Zheng YZ, Tong J, Do XP, Pu XQ, Zhou BT. Prevalence of methylenetetrahydro folate reductase $\mathrm{C} 677 \mathrm{~T}$ and its association with arterial and venous thrombosis in the Chinese population. Br.J Haematol 2000;109:870-4

22. Alluri RV, Mohan V, Komandur S, Chawda K, Chaudhuri JR, Hasan Q. MTHFR C677T gene mutation as a risk factor for arterial stroke: A hospital based study Eur J Neurol 2005;12:40-4

23. Panigrahi I, Chatterjee T, Biswas A, Behari M, Choudhry PV, Saxena R. Role of MTHFR C677T polymorphism in ischemic stroke. Neurol India 2006;54:48-50.

24. Ashfield-Watt PA, Pullin CH, Whiting JM, Clark ZE, Moat S.J, Newcombe RG, et al Methylenetetrahydrofolate reductase $677 \mathrm{C} \longrightarrow \mathrm{T}$ genotype modulates homocysteine responses to a folate-rich diet or a low-dose folic acid supplement: A randomized controlled trial. Am .J Clin Nutr 2002;76:180-6.

25. Deloughery TG, Evans A, Sadeghi A, MeWilliams J, Henner WD, Taylor LM Jr, et al. Common mutation in methylenetetrahydrofolate reductase. Correlation with homocysteine metabolism and late-onset vascular disease. Circulation 1996;94:3074-8

26. Markus HS, Ali N, Swaminathan R, Sankaralingam A, Molloy J, Powell J. A common polymorphism in the methylenetetrahydrofolate reductase gene, homocysteine and ischemic cerebrovascular disease. Stroke 1997;28:1739-43.

27. Notsu Y, Nabika T, Park HY, Masuda J, Kobayashi S. Evaluation of genetic risk factors for silent brain infarction. Stroke 1999;30:1881-6.

28. Jacques PF, Bostom AG, Williams RR, Ellison RC, Eckfeldt JH, Rosenberg IH, et al. Relation between folate status, a common mutation in methylenetetrahydrofolate reductase and plasma homocysteine concentrations. Circulation 1996;93:7-9

Accepted on 22-07-2006 